\title{
Application of Good Governance Principles in Government: Perspective of Public Services
}

\author{
Heru Rochmansjah \\ Institut Pemerintahan Dalam Negeri (IPDN), Indonesia \\ Email: heru_rochmansjah@ipdn.ac.id
}

\begin{abstract}
The community has waited a long time and hopes for the government to implement good governance, namely effective, efficient, accountable, and responsible governance. However, until now, there has not been a comprehensive and systematic strategy in realizing good governance, which is likely due to the broad scope of good governance dimensions and the lack of priority scale due to population diversity and the unavailability of adequate information. So for the initial step, researchers suggest that improving the implementation of public services is the first step in bureaucratic development reform.
\end{abstract}

Keywords: Good Governance, Public Services, Community, Stakeholder

\section{A. INTRODUCTION}

Today in our country, the people hope that the government can carry out good governance, namely the administration of an effective, efficient, transparent, accountable, and responsible government. Effective for the results achieved, accountable means that government administrators are responsible for the policies set and accountable for their performance to all citizens at the end of each year of government administration. The problems experienced by the Indonesian people today are increasingly sophisticated and increasingly laden with problems. The elements of government organizations which should be a role model for many people are stumbling over legal issues. The existence of good governance or often called good governance that has been carried out; the fact is that at present, it is still a dream and is only limited to jargon. Indonesia must wake up from its long sleep. Revolution in every field must be carried out because every product it produces only accommodates the interests of political parties, factions, and groups of people. In contrast, proper state administration should be a serious concern. Transparency can indeed be one solution, but it is not enough to achieve good governance.

The concept of good governance has a broad meaning and is often understood differently depending on the context. In the context of eradicating $\mathrm{KKN}$, good governance is often interpreted as a government that is clean from KKN practices. Some circles interpreted good governance as an accurate translation of democracy by necessitating civic culture to support the sustainability of democracy itself. Generally, 
good governance is defined as good governance management, Kasmawati (2010). Good governance has long been a dream of many Indonesians. Despite their understanding of good governance differently, at least most of them imagined that with good governance, they would be able to have a better quality of governance. Thus, the quality of public services will get better, corruption rates will be lower, and the government will be increasingly concerned with citizens' interests. Mahsyar (2011) defines public service as a series of activities carried out by public bureaucracy to meet the needs of the user population.

It shows that there is no comprehensive and systematic national strategy on how to realize good governance in Indonesia. The government faces many difficulties in formulating policies and programs to improve governance practices. First, governance practices have broad dimensions so that many aspects must be intervened if we want to improve governance practices. Second, information on strategic aspects that need to be prioritized as an entry point in improving governance performance is not widely available. Third, conditions between regions in Indonesia that are very diverse make each region has a different complexity of governance problems. Fourth, the commitment and concern of various stakeholders regarding governance reform vary and, in general, is still low, Maryam, (2017). The various obstacles mentioned above are the cause of the lack of systematic efforts to improve Indonesia's governance performance. Efforts carried out at the center and in the regions are still more sporadic and not well integrated so that the wider community has not widely felt the results. Only patchy and sporadic programs tend to be ineffective because improvements that can be made in one aspect of governance will be co-opted by bad practices that occur in other aspects. This might explain the causes of the emergence of several goods (examples) and corrupt practices (abstinence) in the administration of government in several regions in Indonesia. Even strangely, this example and abstinence can occur in the same jurisdiction and at the same time. This phenomenon shows that there is no comprehensive strategy in developing good governance in Indonesia, both at the central and regional levels. The government's concern to thoughtfully design the reform of governance practices towards better ones is still low. Governments are usually willing to realize the values of good governance insofar as they do not interfere with their interests. The government is willing to be open and participatory if being open and involving broad stakeholders in the process of formulating and implementing policies does not reduce their opportunities to engage in corrupt practices. This has become one of the causes of exemplary and abstinence in the administration of a region simultaneously.

Considering the development of good governance has high complexity and significant obstacles, it is needed a strategic step to start the practice of governance. In 
this paper, the implementation of public services was chosen as the entry point and prime mover (prime movers) to realize good governance. The concept of good governance arises because of dissatisfaction with government performance, which has been believed to be the organizer of public affairs. Implementing good governance practices can be done in stages following the government's capacity, civil society, and market mechanisms. One strategic choice for implementing good governance in Indonesia is through the delivery of public services. Public services are a benchmark for the successful implementation of tasks and measuring government performance through the bureaucracy. Public service as a prime mover is also considered necessary by all actors from the element of good governance. Public officials, elements in civil society, and the business world are interested in improving public service performance. Three essential reasons are underlying the renewal of public services that can encourage the practice of good governance in Indonesia. First, improving the performance of public services is considered necessary by stakeholders, namely the government, citizens, and the business sector. Second. Public service is the domain of the three elements of governance to conduct very intensive interactions. Third, the values that have characterized the practice of good governance are translated more easily and clearly through public services, Dwiyanto (2005).

\section{B. METHODOLOGY}

In this study, researchers used a qualitative research approach. Qualitative research. Through a qualitative approach, researchers find and describe a phenomenon with a unique character associated with public service as a means of realizing good governance. The reason for using qualitative research methods in this study is that it is considered appropriate. There is a match between the characteristics of qualitative research with the phenomenon under study. In this study, researchers used descriptive research, which is only limited to describing a phenomenon or object as it is, without any intention of drawing conclusions that are generally accepted. Besides, the reason for using descriptive qualitative research is that this research aims to capture the phenomenon of information, especially concerning the focus of the study. This approach can also present a holistic form or thorough.

\section{RESULTS AND DISCUSSION}

From the results of Ulbert Silalahi's research (Pramusinto et al., 2005) on public services before the reforms, it was obtained that the level of satisfaction of the state apparatus services provided to the public showed an average percentage of $33.7 \%$ which was categorized as low. The form or form of public service, which is the sin of service of the attitude of the service of the state apparatus, can be various forms and 
forms, including apathy, refusing to deal, being cold, looking down, working mechanically, strict on procedures and often pinging people. Likewise, in line with the above research results, in 2002 the results of research by Agus Dwiyanto et al. in Ginting and Haryati (2011) obtained data in his book that the performance of government bureaucratic services during the reform period even though it has been running for approximately 4 (four) years is not much significantly changed. The state apparatus or bureaucrats, or government bureaucracy, still shows a low degree of accountability, responsiveness, and efficiency in public services administration. Even empirically in the reform era, it is evident that KKN (Collusion, Corruption, and Nepotism) among bureaucrats is bolder and transparent. The empirical situation of public services, as revealed in advance, shows us that the focus of interest of our apparatus is not yet focused on its primary task. Public service as the main task of the bureaucracy or the state apparatus is still very much influenced by the government system, prioritizing power or authority. The government system ignores services to the community and government or bureaucratic systems that are not responsive to what is needed, needed, and desired by the community. Government systems prioritize political authority rather than political commitment, one of which is customer-oriented or customer perspective or serviceoriented to the interests and needs of the community From now on, we must use to put down and strengthen the function or role of the bureaucracy or the government as its primary function, namely public service. At the same time, the functions that have been held by the bureaucracy or the government must be left to the private sector and the community. This is all as a consequence we move from a government that focuses on authority to governance that focuses on collaboration or compatibility between the public (government/bureaucracy), private (private), and community (community), Pramusinto et al. (2005).

The most fundamental question is, why is public service reform a strategic point for building good governance? Why not other aspects of government activity? Aren't there still many other problems the government faces that are also very urgent to be dealt with? These questions are fundamental to answer so that the choice of establishing service delivery practices through public service reform is genuinely believed to bring the Indonesian government towards good governance practices.

Quoting Dwiyanto's opinion (2005), there are several considerations why public service is a strategic point to start developing good governance in Indonesia, including:

1. With public services, the values that characterize good governance can be done more efficiently and visibly by the government bureaucracy. Values that characterize good governance practices such as efficiency, transparency, accountability, and participation can be translated relatively quickly in the 
administration of public services rather than institutionalizing these values in all aspects of government activities.

2. Public services involve the interests of all elements of governance. Government, civil society, and market mechanisms have high interests and involvement in this realm. Public services have a high stake and are an essential gamble for the three elements of governance because the good and bad practice of public services is very influential on all three. The fate of a government, both at the central and regional levels, will be significantly influenced by their success in realizing excellent public services. The success of a regime and the authorities in building the legitimacy of power is often influenced by their ability to provide excellent public services and satisfy citizens. Likewise, improving public services will also reduce the costs of bureaucracy, which can improve the welfare of citizens and the efficiency of market mechanisms. Thus, public service reform will receive broad support.

3. Public services can arouse public support and trust. Public services have been the domain where the State represented by the government has integrated with non-government institutions. In this realm, there was a very intense struggle between the government and its citizens. Citizens and the wider community strongly felt poor governance practices in the delivery of public services. This means that if there is a significant change in the public service domain, the benefits can be felt directly by the citizens and the wider community. Success in realizing good governance practices in the realm of public services can generate support and trust from the broader community

that building good governance is not just a myth but can become a reality.

4. By improving public services, tolerance for lousy governance practices is expected to be stopped. The results of the Governance and Decentralization Survey 2002 (GDS 2002) show that most citizens consider it reasonable to practice extortion (extortion) and instead feel relieved because the service process can be finished soon, becoming an indicator that citizens of the nation are becoming increasingly tolerant of lousy governance practices. This can not only encourage citizens to develop survival mechanisms with the practice of bad governance, but also avoid efforts to build good governance. If things like this continue to happen and become more widespread, of course, it is hazardous for the survival of the nation's life. By making the practice of public services as an entry point in 
building good governance, it is hoped that tolerance for lousy governance that can expand can be stopped.

5. By improving public services, it is hoped that actors outside the State can respond to public problems. Governance is broader than government because governance practices involve elements of civil society and market mechanisms. In public service, the involvement of elements of civil society and market mechanisms has been happening a lot, so that the practice of governance in the realm of public service is not a new thing anymore. This is an advantage to start change because of the involvement and market mechanism before it already exists. Next, what is needed is to reposition the three elements and redistribute proportional and complementary roles among government, civil society, and market mechanisms so that synergies can be developed.

6. Benchmarks and indicators of public service practice can be easily carried out. Public services with good governance concepts such as efficient, nondiscriminatory, highly responsive, and have high accountability can be easily assessed and measured. Simple benchmarks and indicators can be used easily by the organizer, user users, and other stakeholders. All stakeholders can quickly assess more than that, the progress of developing public services with a good governance perspective.

\section{CONCLUSION}

The public has been waiting and has been impatient, waiting for the birth of good governance. It is not possible to take all necessary actions at the same time to develop good governance, because time, energy, budget, and other resources owned by the government and society are limited. However, real steps must be taken by the government immediately. For this reason, reforming the government bureaucracy can be a strategic first step. By giving priority to improving government bureaucracy, the impact on accelerating the realization of good governance is enormous. Even more, concrete, if the improvement of the practice of public service delivery becomes the initial agenda of bureaucratic reform. The delivery of public services must become the core business of government bureaucracy. With the government's success in improving public administration so that it becomes efficient, responsive, participatory, and accountable, the government can improve the performance of the bureaucracy and build good governance. 


\section{REFERENCES}

1. Ashari, E. T. (2010). Reformasi Pengelolaan SDM Aparatur, Prasyarat Tata Kelola Birokrasi Yang Baik. Jurnal Borneo Administrator, 6(2).

2. Dwiyanto, A. (2005). Mewujudkan Good Governance Melalui Pelayanan Publik. Yogyakarta: Gajah Mada University Press.

3. Ginting, R., \& Haryati, T. (2011). Reformasi Birokrasi Publik di Indonesia. CIVIS, 1(2/Juli).

4. Hardiyansyah, H. (2018). Kualitas Pelayanan Publik: Konsep, Dimensi, Indikator dan Implementasinya. Gava Media.

5. Kasmawati, A. (2010). Implikasi Hukum Kebijakan Desentralisasi dalam Hubungan Kewenangan antartingkat Pemerintahan Negara Kesatuan. Jurnal Hukum IUS QUIA IUSTUM, 17(4), 552-566.

6. Kriyantono, R. (2015). Konstruksi humas dalam tata kelola komunikasi lembaga pendidikan tinggi di era keterbukaan informasi publik. Pekommas, 18(2), 222394.

7. Muhi, A. H. (2011). Membangun good governance pada perguruan tinggi di indonesia. Tersedia secara online di: http://alimuhi. staff. ipdn. ac. id/wpcontent/uploads/2011/04/MEMB. GOOD_. GOV_. PADA_. PT_. pdf [diakses di Bandung, Indonesia: 15 Januari 2017].

8. Mahsyar, A. (2011). Masalah Pelayanan Publik di Indonesia dalam Perspektif Administrasi Publik. Otoritas: Jurnal Ilmu Pemerintahan, 1(2).

9. Mindarti, L. I. (2016). Manajemen Pelayanan Publik: Menuju Tata Kelola Yang Baik. Universitas Brawijaya Press.

10. Pramusinto, A., Kumorotomo, W., \& Purwanto, E. A. (2005). Kajian Historis dan Isuisu Kontemporer untuk Merumuskan Agenda Masa Depan Ilmu Administrasi Publik. Jurnal Ilmu Sosial dan Politik, 9(2005).

11. Rosyada, A. A. (2016). Analisis Penerapan Prinsip Good Governance Dalam Rangka Pelayanan Publik di Badan Pelayanan Perizinan Terpadu Satu Pintu Di Kota Samarinda. Journal Ilmu Pemerintahan, 4(1), 2016.

12. Siti Maryam, N. (2017). Mewujudkan good governance melalui pelayanan publik. JIPSI-Jurnal Ilmu Politik dan Komunikasi UNIKOM, 6.

13. Sari, D. (2013). Effects of government internal control systems, implementation of government accounting standards, completion of audit findings on the application 
of good governance principles (Research on local governments in the Provinces of West Java and Banten).

14. Sitohang, E. (2014). Prinsip hukum dalam tata kelola rumah sakit. Yuridika, 29(1).

15. Putra, H. S. (2017). Village Governance in Realizing Good Governance in Kalibelo Village, Kediri Regency. Journal of Youth Politics, 6 (2), 110-119. 